NASZA DERMATOLOGIA Online

OUR DERMATOLOGY Online Nil

Competing Interests:

None declared

\section{UNILATERAL LATEROTHORACIC EXANTHEM IN A PREGNANT WOMAN - CASE REPORT}

\author{
Anca Chiriac ${ }^{1}$, Anca E. Chiriac ${ }^{2}$, Liliana Foia ${ }^{2}$ \\ ${ }^{I}$ Nicolina Medical Center, Department of Dermatology Iasi-Romania \\ ${ }^{2}$ University of Medicine, Gr T Popa Iasi-Romania
}

Corresponding author: Anca Chiriac, MD PhD

ancachiriac@yahoo.com

\begin{abstract}
Unilateral laterothoracic exanthem (ULE) (also termed asymmetric periflexural exanthem of childhood APEC) has been linked to viral infection, in particular parvovirus B-19, citomegalovirus and Ebstein Barr virus. Its prevalence is higher during spring and winter, most published reports involve white people. The diagnosis is clinical, the virusological tests, in most of the cases, are negative. The exanthem is self-limited, it resolves in four-six weeks, it requires only symptomatic treatment. Our case is particular by the appearance in a pregnant woman to whom we have not succed to identify any virus involved, with wonderful clinical results under no medication. We follow the evolution of the pregnancy.
\end{abstract}

Key words: exanthem; unilateral laterothoracic exanthem; pregnancy

\section{Introduction}

Unilateral laterothoracic exanthem (ULE) (also termed asymmetric periflexural exanthem of childhood APEC) was first described in 1962 in the United States, but the name was given in 1992 by Bodemer-de Prost [1]. It usually manifests as unilateral erythematous papules surounded by white halo, without systemic symptoms.

ULE has been linked to viral infection, in particular parvovirus B-19, citomegalovirus and Ebstein Barr virus [2]. While ULE most commonly occurs in children, ULE can occur in adults, we describe a typical case, appeared in a pregnant woman (Vth month of pregnancy) with a 2 weeks favorable evolution $[1,3]$.

\section{Case report}

A 32 year-old woman presented in our Department with an asymptomatic 2-day history of a unilateral erythematous macular eruption on her left side of the trunk, scatered lesions on the hips, no systemic symptoms, no palpable lymph nodes. She was in good health state. She was pregnant in Vth month with her first baby.

She denied any drug intake, no previous ilness, no symptoms before the onset of the eruption.

The lab investigations showed a slight anemia, leucocytosis with neutrophilia and the virusology results were negative for Parvovirus B19, Ebstein Barr virus and citomegalovirus. We did not recommend any therapy, just daily control and the lesions fadded and dissapeared in 15 days, with minor hyperpigmentation.

\section{Discussion}

Unilateral laterothoracic exanthem is also known as asymetric periflexural exanthem in children (APEC) and it is mainly described in children between one and five years old, although adults can be affected too. Its prevalence is higher during spring and winter, most published reports involve white people [1,3].

The diagnosis is clinical, the virusological tests, in most of the cases, are negative, although ULE is linked to viruses: parvovirus B-19, citomegalovirus and Ebstein Barr virus [2]. The exanthem is self-limited, it resolves in four-six weeks, it requires only symptomatic treatment.

Our case is particular by the appearance of ULE in a pregnant woman to whom we have not succed to identify any virus involved, with wonderful clinical results under no medication. We follow the evolution of the pregnancy. 


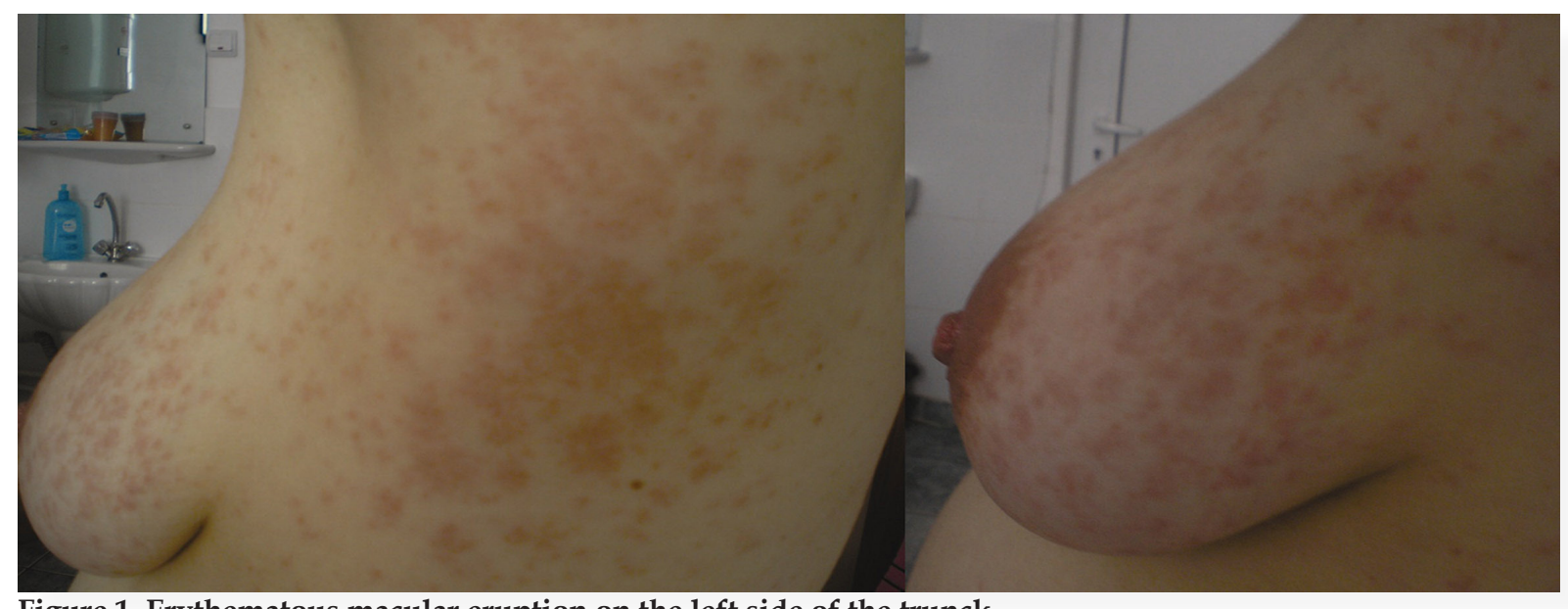

Figure 1. Erythematous macular eruption on the left side of the trunck

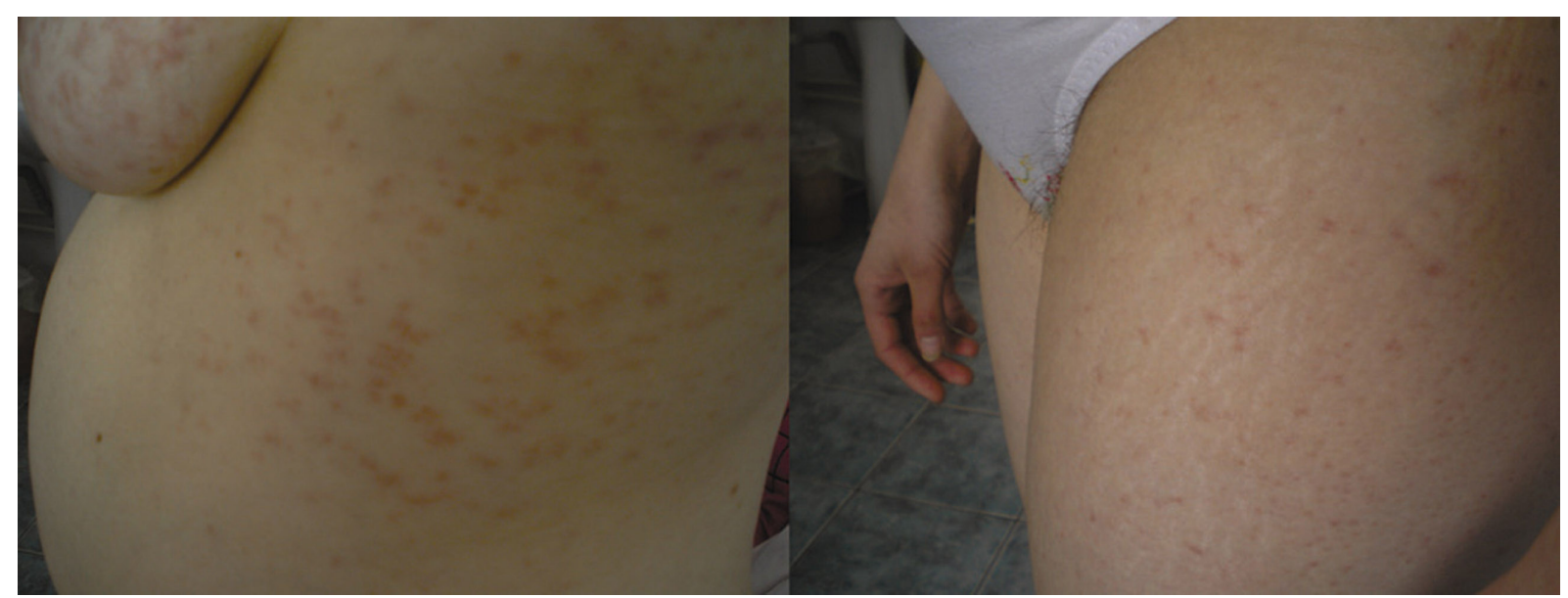

Figure 2. The same lesions on the left arm and thigh

\section{REFERENCES}

1. Ferrante G, Andrei I: Metelitsa Unilateral laterothoracic exanthem CMAJ. 2012;184:322.

2. Scheinfeld N: Unilateral laterothoracic exanthema with coincident evidence of Epstein Barr virus reactivation: exploration of a possible link. Dermatol Online J. 2007;13:13.

3. Bodemer C, de Prost Y: Unilateral-laterothoracic exanthem in children: a new disease? J Am Acad Dermatol. 1992;27:693-6.

Copyright by Anca Chiriac, et al. This is an open access article distributed under the terms of the Creative Commons Attribution License, which permits unrestricted use, distribution, and reproduction in any medium, provided the original author and source are credited. 